\title{
Editorial
}

\section{Mine Waste Characterization, Management and Remediation}

\section{Karen A. Hudson-Edwards ${ }^{1, *}$ and Bernhard Dold ${ }^{2}$}

1 Department of Earth and Planetary Sciences, Birkbeck, University of London, Malet St., London WC1E 7HX, UK

2 SUMIRCO (Sustainable Mining Research \& Consult EIRL), Casilla 28, San Pedro de la Paz 4130000, Chile; E-Mail:bernhard.dold@gmail.com

* Author to whom correspondence should be addressed; E-Mail: k.hudson-edwards@bbk.ac.uk; Tel.: +44-203-073-8030.

Academic Editor: Stephen E. Haggerty

Received: 28 October 2014 / Accepted: 6 January 2015 / Published: 19 January 2015

Mining is a vital part of the Global economy, but the extraction of metals, metalloids, and other mineral products generates vast quantities of liquid and solid waste. Currently the volume is estimated at several thousand million tons per annum, but is increasing exponentially as demand and exploitation of lower-grade deposits increases. The high concentrations of potentially toxic elements in these wastes can pose risks to ecosystems and humans, but these risks can be mitigated by implementing appropriate management or remediation schemes. Although there are a large number of such schemes available, there is still a need to research the processes, products, and effectiveness of implementation, as well as the nature of the mine wastes themselves. This Special Issue is aimed at bringing together studies in the areas of mine waste characterization, management, and remediation, to review the current state of knowledge and to develop improvements in current schemes. Fourteen manuscripts are published for this Special Issue, and these are summarized below.

Due to the large-scale nature of mine wastes, characterization is often done at regional scales. In this regard, Buzzi et al. [1] describe a method whereby hyperspectral high spatial resolution HyMap data can be used to map mainly abandoned massive sulfide mine wastes from the Iberian Pyrite Belt, Southwest Spain. Pattelli et al. [2] describe the flood-related mobilization of sediment-borne $\mathrm{Hg}$ from the Mount Amiata mining district in southern Tuscany, Italy, the fourth largest $\mathrm{Hg}$ district worldwide, which produced 102,000 metric tons of $\mathrm{Hg}$ from the 1860s to 1980. The processes and products of contaminant mobility at redox-transition zones, leading to diffuse metal contaminant inputs into river systems, is reviewed by Lynch et al. [3]. 
Acid generation from oxidation of sulfide minerals, such as pyrite and pyrrhotite, in mine wastes is one of the most significant issues facing the mining industry [4]. Dold [5] reviews the complex biogeochemical and mineral dissolution processes in sulfidic mine tailings leading to the formation of acid mine drainage (AMD). Mumford et al. [6] and Langman et al. [7] describe long-term acid generation from sub-Arctic oil shales and waste rock from the Diavik Diamond Mine in the Northwest Territories of the Canadian Arctic, respectively. In both cases, the acid generation potential is dependent on the concentrations of sulfide, neutralization reactions with carbonates and Al-bearing minerals and temperature.

Secondary Fe-bearing oxyhydroxysulfate, hydroxide and oxyhydroxide minerals play a major role in sequestering metals and metalloids from mine wastes [8]. The formation of jarosite and soluble Fe-sulfates in the tailings' impoundments at the $\mathrm{Zn}-\mathrm{Pb}-\mathrm{Ag}$ Pan de Azúcar mine, NW Argentina, is described by Murray et al. [9]. Alarcón et al. [10] investigate the potential for As retention by secondary jarosite, schwertmannite, ferrihydrite, and goethite from coastal tailings under a marine flood scenario.

Large volumes ( $\sim 100$ s of millions of tons) of smelting slags are produced annually worldwide, and these contain elevated concentrations of metals including $\mathrm{Al}, \mathrm{Cr}, \mathrm{Cu}, \mathrm{Fe}, \mathrm{Mn}, \mathrm{Pb}$, and $\mathrm{Zn}$ [11]. The primary phases and secondary weathering products of smelting slag at an abandoned mine site in SW Japan are described by Sueoka and Sakakibara [12]. High concentrations of Zn occur in willemite, and of $\mathrm{Fe}, \mathrm{Zn}, \mathrm{Cu}, \mathrm{Sn}, \mathrm{Pb}, \mathrm{As}$, and $\mathrm{Cd}$ in matte drops, but these weather to form Fe hydroxides, releasing the metals and metalloids to local aqueous and soil environments.

Several promising avenues for the management and remediation of mine wastes are outlined in this special issue. Due to increasing amounts of mine wastes generated annually, and environmental and social issues surrounding disposal on land, mining companies are seeking alternative methods of disposal. Dold [13] reviews the mineralogical and geochemical issues arising from submarine tailings disposal. Diaby and Dold [14] continue the marine disposal theme by describing the results of the implementation of artificial wetland remediation cells on oxidizing marine shore tailings deposits. The wetland implementation is most effective and rapid when the system is water saturated, and when $\mathrm{pH}$ and redox are favorable for precipitation and immobilization processes.

Other techniques for managing and remediating mine wastes involve the use of heat and other waste products. The use of thermal desorption to volatilize $\mathrm{Hg}$ from $\mathrm{Hg}$-contaminated soil and mine wastes is described by Navarro et al. [15], and Mäkitalo et al. [16] outline the properties of green liquor dregs (GLD), alkaline residual materials produced by sulfate paper mills. Johnson [17] reviews recent advances in biotechnologies using microorganisms that can reduce the reactivity of potentially hazardous mine tailings and selectively remove metals and other contaminants from mine waters.

The studies published in this special issue contribute to knowledge of how mine wastes are mobilized, neutralized and weathered, and of novel methods for how these wastes can be managed and remediated. The more novel biotechnological, in situ and perhaps, nanotechnological, mitigation methods hold the most promise for future development, given their potentially low environmental impacts and economic benefits. The future of mine waste mitigation depends on the type of knowledge presented in this special issue, and on ongoing regional- to atomic-scale research on the characteristics and short- to long-term behavior of mine wastes. This work is essential, given the huge physical, toxic element and carbon footprints of mine wastes, the uncertainties around the impacts of current 
management and remediation schemes, new types of wastes generated from new types of commodities (e.g., oil sands, lithium, heavy rare earth elements (HREEs)), and the growing global amounts of mine waste.

\section{Conflicts of Interest}

The authors declare no conflict of interest.

\section{References}

1. Buzzi, J.; Riaza, A.; García-Meléndez, E.; Weide, S.; Bachmann, M. Mapping changes in a recovering mine site with hyper spectral airborne HyMap imagery (Sotiel, SW Spain) Minerals 2014, 4, 313-329.

2. Pattelli, G.; Rimondi, V.; Benvenuti, M.; Chiarantini, L.; Colica, A.; Costagliola, P.; Di Benedetto, F.; Lattanzi, P.; Paolieri, M.; Rinaldi, M. Effects of the November 2012 flood event on the mobilization of $\mathrm{Hg}$ from the Mount Amiata mining district to the sediments of the Paglia River Basin. Minerals 2014, 4, 241-256.

3. Lynch, S.F.L.; Batty, L.C.; Byrne, P. Environmental risk of metal mining contaminated river bank sediment at redox-transitional zones. Minerals 2014, 4, 52-73.

4. Nordstrom, D.K. Mine waters: Acidic to circumneutral. Elements 2011, 7, 393-398.

5. Dold, B. Evolution of acid mine drainage formation in sulfidic mine tailings. Minerals 2014, 4, 621-641.

6. Mumford, K.A.; Pitt, B.; Townsend, A.T.; Snape, I.; Gore, D.B. Long-term acid-generating and metal leaching potential of a sub-Arctic oil shale. Minerals 2014, 4, 293-312.

7. Langman, J.B.; Moore, M.L.; Ptacek, C.J.; Smith, L.; Sego, D.; Blowes, D.W. Diavik waste rock project: Evolution of mineral weathering, element release, and acid generation and neutralization during a five-year humidity cell experiment. Minerals 2014, 4, 257-278.

8. Jamieson, H.E. Geochemistry and mineralogy of solid mine waste: Essential knowledge for predicting environmental impact. Elements 2011, 7, 381-386.

9. Murray, J.; Kirschbaum, A.; Dold, B.; Guimaraes, E.M.; Miner, E.P. Jarosite versus soluble iron-sulfate formation and their role in acid mine drainage formation at the Pan de Azúcar mine tailings (Zn-Pb-Ag), NW Argentina. Minerals 2014, 4, 477-502.

10. Alarcón, R.; Gaviria, J.; Dold, B. Liberation of adsorbed and co-precipitated arsenic from jarosite, schwertmannite, ferrihydrite, and goethite in seawater. Minerals 2014, 4, 603-620.

11. Piatak, N.M.; Parsons, M.B.; Seal, R.R., II. Characteristics and environmental aspects of slag: A review. Appl. Geochem. 2014, doi:10.1016/j.apgeochem.2014.04.009.

12. Sueoka, Y.; Sakakibara, M. Primary phases and natural weathering of smelting slag at an abandoned mine site in southwest Japan. Minerals 2013, 3, 412-426.

13. Dold, B. Submarine tailings disposal (STD) - A review. Minerals 2014, 4, 642-666.

14. Diaby, N.; Dold, B. Evolution of geochemical and mineralogical parameters during in situ remediation of a marine shore tailings deposit by the implementation of a wetland cover. Minerals 2014, 4, 578-602. 
15. Navarro, A.; Cañacas, I.; Rodríguez, J. Thermal treatment of mercury mine wastes using a rotary solar kiln. Minerals 2014, 4, 37-51.

16. Mäkitalo, M.; Maurice, C.; Jia, Y.; Öhander, B. Characterization of green liquor dregs, potentially useful for prevention of the formation of acid rock drainage. Minerals 2014, 4, 330-344.

17. Johnson, D.B. Recent developments in microbiological approaches for securing mine wastes and for recovering metals from mine waters. Minerals 2014, 4, 279-292.

(C) 2015 by the authors; licensee MDPI, Basel, Switzerland. This article is an open access article distributed under the terms and conditions of the Creative Commons Attribution license (http://creativecommons.org/licenses/by/4.0/). 